\title{
A Conversation with Sabino Cassese
}

\author{
Alec Stone Sweet ${ }^{1, \star}$ and Giacinto della Cananea ${ }^{2}$ \\ ${ }^{1}$ Professor, Chair of Comparative and International Law, Faculty of Law, Hong Kong University, Hong Kong and ${ }^{2}$ Professor, \\ Department of Law, Bocconi University, Milan, Italy \\ *Corresponding author: asweet@hku.hk
}

(Received 24 November 2021; accepted 24 November 2021)

Keywords: International Law; Judges; Constitutions; Fundamental rights; Constitutional courts

\section{A. Training and Academia}

S. Cassese: I knew the hard sciences were not for me. I preferred history or philosophy. But a degree in these fields would not open the road to a job. I chose law, then brought my interest in history and philosophy to my legal studies.

I was a student at the Scuola Normale Superiore, now the Scuola Sant'Anna, in Pisa. It was much more like a small campus in the United States, in that students and professors had close contact. Here I met my most important influence and mentor: Professor Massimo Severo Giannini [1915-2000]. I met him when I was a second-year student in 1953 and worked with him for nearly half a century.

I was also heavily influenced by two people from outside the academic world. The first was Enrico Mattei [1906-1962], a leading politician who was also the head of the Ente Nazionale Idrocarburi [ENI] [a state-owned oil and gas corporation]. I worked with him from 1957 to 1962. I had won scholarships to Paris and the USA, but I chose to become a lawyer at the ENI which, at that point, was the most important place to work in Italy. Under Mattei, the ENI offered Italy the possibility of developing a new model of a state entity, more modern and efficient. Everything inside it was influenced by American advisors. I was promoted very quickly. At twenty-four years old, I headed the ENI's legal department, which would be impossible in Italy today. When Mattei died, I decided to leave.

The other was a man who had been a refugee in the U.S. during the war, Luigi Sturzo [1871-1959], a leading figure in the Partito Popolare, subsequently the Democrazia Cristiana. I was in close touch with him for the last three years of his life. Sturzo was an important politician, active even before the fascists came to power. He had a strong interest in sociology, especially after his return to Italy. He started a journal called Sociologia, for which I wrote articles and book reviews.

At ENI, I also worked with a senior civil servant, Gaetano Stammati [1908-2002]. He was a public finance professor, and later a member of the Italian government. We worked closely together on the implementation of the Treaty of Rome, focusing on the issue of state subsidies aids. In that role, I saw directly how important European law could be.

Question: How did you manage the transition from a managerial position in a state corporation to a member of a law faculty? Had the academic world become foreign to you? 
S. Cassese: Not at all. While at the ENI, I kept my position as a voluntary assistant with Giannini, who was appointed as a professor at the University of Rome Law School in 1958. I never considered continuing to work in industry. I also managed to write articles and a book that was published in 1962. There was a sacrifice, as I had to spend weekends and nights to complete the research and writing. At the same time, I was appointed as a staff member of the Parliamentary commission on monopolies, where I spent nearly a year. It was an interesting experience, introducing me to the field of competition law, and left me with time to write a book on state entities and public services. ${ }^{1}$

Question: Among academics outside of Italy, you have a reputation as a cosmopolitan. Indeed, you began to study global and comparative law in the 1960s, without ever giving up your interest in Italian public law. How did you develop these strange interests? Not in Pisa, presumably?

S. Cassese: I was convinced that comparison is crucial to many related fields: Economists, historians, sociologists, political scientists, and lawyers should all be comparatists. Through ENI, I had many foreign contacts. I became, for example, the ENI delegate to the International Centre of Research and Information on the Public, Social and Cooperative Economy (CIRIEC), an international network of think tanks and scholars.

Remember what Alexis de Tocqueville [1805-1859] wrote, "One will never understand the French Revolution if one studies only the French Revolution." [L'ancien régime et la Révolution] That's the key. But in law schools, one can pay a price, punished for being "different." Take Hans Kelsen's story. Kelsen [1881-1973] went to Berkeley [in 1942] and wanted to be appointed professor in the law school. But he remained in the political science department because, in America, Kelsen was not considered to be a lawyer.

At the same time, there existed a tradition of openness in Italian legal culture, especially to Germany, France, and Spain. An example is Vittorio Emanuele Orlando (1860-1952). He studied in Munich, after graduation from Palermo, before founding what would become the "school" of modern Italian public law. But it is true that, when I began my teaching career, most professors had little contact with foreign legal cultures, especially the English and American.

Question: You have often noted that the United States, and, in particular, John Merryman [1920-2015], helped develop your interest in comparative law.

S. Cassese: I was one of the very few people in the world who got the Fulbright scholarship three times in my life, so I was able to spend time in the U.S. in that context and others. I went to Berkeley first in 1965, when Merryman was in Rome. As soon as I returned to Italy, I met him and we became great friends. Merryman was a very open and kind person. As you know, he wrote these three articles on the Italian style for the Stanford Law Review, ${ }^{2}$ and these are the result of many conversations that we had, along with Mauro Cappelletti [1927-2004].

Question: We use the words "public law" to categorize multiple strands of law, but there are huge differences in how administrative and constitutional scholars and judges think about their respective domains. Constitutional law professors ignored European law for a very long time, for instance, putting it in a box labelled "public international law."

S. Cassese: I share the German view on this point, that there is one branch of law, a unitary branch, that we call public law. But there are different traditions. Constitutional law was studied once as part of political science, with little reference to administrative law. Administrative law was born of the administrative judge, "sur les genoux du Conseil d'État."

The question also raises important points about the uses of "foreign" law. In the 1940s and 1950s, the approach of Italian constitutional law scholars resembled that of Antonin Scalia (1936-2016). If one is the sole judge of one's own constitution, then foreign law is irrelevant. If one writes a new constitution, one can look to foreign constitutions. This was the general view

\footnotetext{
${ }^{1}$ Sabino Cassese, Partecipazioni Pubbliche ed Enti di Gestione (1962).

${ }^{2}$ John H. Merryman, The Italian Style I: Doctrine, 18 StAN. L. ReV. 39 (1965-1966); John H. Merryman, The Italian Style II: The Law, 18 StAn. L. ReV. 396 (1965-1966); John H. Merryman, The Italian Style III: Interpretation, 18 STAN. L. REV. 583 (1965-1966).
} 
of Italian constitutional lawyers when I was a student. In 1946 and 1947, lawyers were open to comparative law, under the guidance of Giannini, who was in charge of preparing the work of the new constituent assembly. They translated and studied many foreign constitutions in preparation for the drafting of the Italian constitution. But once the Constitution was written, this stopped. Today, it has changed again. The Italian Constitutional Court pays close attention to how every important high court has decided cases that are similar to those arising in Italy.

It's also true that the trajectories of the two fields-constitutional and administrative law-were quite different. In the administrative law tradition, the law is constructed along a path: It moves from case law to doctrine to political science, while the opposite was true for constitutional law. But then constitutional law became case law, because finally there was a new Constitutional Court. And what do professors do when they have a new court? They start studying and commenting on the judgements. Today, if you read the constitutional and public law journals, there is nothing of the old political science approach. No one writes on constitutional structure or political parties. There are only commentaries and articles on the case law, on jurisprudence.

Question: We would predict as much from Merryman, who wrote about this phenomenon in The Civil Law Tradition, ${ }^{3}$ with respect to the civil codes of Europe. What happened in the constitutional context had already taken place with respect to scholarship on the codes, which had rapidly become commentary on the case law of the courts of cassation.

S. Cassese: The creative role of lawyers is exercised mainly through commentaries on jurisprudence, and many law professors also practice law. It is for this reason that scholars without a judge feel alone. So, when new courts emerged, they focus on the judge. This trend is clear in the French $19^{\text {th }}$ century administrative law, as well as in the evolution of contemporary Italian constitutional law. Scholars now pay a great deal of attention to the work of the Constitutional Court, while not sufficiently considering the importance of parliament, the executive, political parties, the constitutional role of labor unions, and so on.

Question: As a scholar, did you see your role more in the classic style depicted by Merryman, of constructing the law in partnership with courts through doctrinal commentary? Or did you think of yourself as an outsider-observer of the system? More generally, how critical of a court should a professor be?

S. Cassese: If you are a member of a Constitutional Court, you may sometimes try to push the Court out of its routines, but you are still acting from the inside. But there are counter-forces, since most judges always will seek to follow precedent, and following precedent makes one "passive." Lawyers and judges are people who believe that there can never be anything really new.

As a comparativist, I was a follower of Merryman. He helped us in Europe understand that there were many lawmakers, not just the legislature. The executive and the judiciary make law all the time. I never focused on jurisprudence and the work of the courts, but on all the institutions, and the overall process of constructing the law. As for the attitude of Italian scholarship, I would say that the courts were never thought to be untouchable; the idea that one can criticize the courts was always accepted. Commentators can develop a critical attitude.

Question: What was the attitude of administrative law scholars to the newly established constitutional court?

S. Cassese: At the beginning, the Constitutional Court remained a foreign body, for a very simple reason. Constitutional law was considered a separate field from administrative law. The constitutional court was very slow to enter the field of administrative law, issuing very few important decisions. In addition, the constitutional court was-and remains in some respects - a prisoner of the mentality of other judges. I call this situation the "hyper-judicialisation" of the Constitutional Court. Among the fifteen members, there are five judges nominated by the judiciary; the fact that three of them come from the Court of Cassation has had an impact on

${ }^{3}$ John Henry Merryman, The Civil Law Tradition: An Introduction to the Legal Systems of Europe and Latin AMERICAN ch. 9-10 (2007). 
the Court's evolution. By "hyper-judicialisation," I mean that the Court models itself as ordinary courts do, conceiving of itself as a judge of a code-the Constitution. But the Constitutional Court is not included in the chapter of the Constitution on the judiciary. It formally lies outside of the judiciary. The Court could have had a very different, and more positive, role in the constitutional and administrative life of Italy, had it not become the prisoner of this "hyper-judicial" mentality.

An example. The Court has been always inclined to be very strict on "admissibility" requirements - when the Court decides if it is to decide or not. In the judicial mode, decisions on justiciability are vitally important, basic to the court's operations. But a constitutional jurisdiction occupies a different place in the framework of separation of powers. A constitutional court should not adopt the formalistic attitude of a judge sitting on an ordinary court. And it should not adopt an attitude of deference to any other institution. I heard many times from my colleagues: This question is institutionally or politically controversial, so how can we avoid deciding it? They are looking to escape, rather than to solve the problem. This lack of courage, timidity, is not appropriate for a constitutional court.

\section{B. Member of the Italian Constitutional Court}

Question: Before you were appointed to the Court, you must have thought about being a judge, if only to consider how you would have decided a difficult case, given the chance. Looking back, what surprised you most about life on the Court once you joined it? Would you advocate reforming the Court in any important way?

S. Cassese: I never considered the possibility of becoming a constitutional judge. After the position was offered, it took me three months to take a decision because I did not want it. I wanted to remain a teacher and a scholar.

On the Court, what surprised me most was its genuine collegiality. People respected one another and were remarkably open to genuine debate. I was told that one of my predecessors, Giuliano Vassalli [1915-2009], one of the leading figures of the criminal law in Italy, a former Minister of Justice, and a former President of the Court, set the right tone. He would present his conclusions, when acting as judge-rapporteur, by saying, "this is my proposal, but I am now ready to listen to your opinions." He was very much open to changing his mind, based on the Court's deliberations, and this approach has been honored since.

What I disliked the most was just mentioned-the Court's hyper-judicialization-which results from it modeling itself after an ordinary court, rather than a true constitutional jurisdiction. Imagine if the Court could think beyond that model and had the courage to assume a more expansive role! I support an important change in this direction. In the Italian system, the President of the Republic is all alone in any great crisis. He's the only person who can redirect Italian politics if parliamentary democracy is failing or threatened. He is a politician, but not a "politician" in the sense of party politics. In such a situation, the constitutional court could also assume a similar role, as an agent of the constitution.

According to the rules, the President of the Court is elected for three years, renewable once. According to tradition, the President is elected by seniority. This means that he plays this role for a much shorter term. To be effective, the President of the Court needs to be elected for at least five or six years. If we accept the idea that constitutional judges are outside of the political sphere, we limit the authority of the Constitution to our detriment. With just a few changes, the President of the Court could become the state's "public moralist," in the best sense of the term, much as Stefan Collini argues in his book. ${ }^{4}$ Not through judgements of course, but speaking regularly on the state of Italian democracy and the political system from the point of view of the Constitution.

The Italian Court has accepted its own hyper-judicialization too easily. It has adopted the traditional mindset of the Court of Cassation. And it is too anxious to avoid becoming involved in

${ }^{4}$ Stefan Collini, Public Moralists: Political Thought and Intellectual Life in Britain 1850-1930 (1991). 
"politics." But whenever a constitutional court adjudicates an important case, it will become involved in politics. It is normal that the court will be criticized for any decision it takes. It should accept this fact and embrace a more expansive role.

Question: An important ruling always revises the constitution as well.

S. Cassese: Every time constitutional judges interpret the constitution, they revise it. Rewriting the constitution is how a constitutional court keeps the written text alive, and how it does its job. In the end, despite hyper-judicialization, the court has shown itself ready to do this, and does so, day-to-day.

Question: On the German Court, members gradually specialize in specific substantive areas of law through their appointment as judge-rapporteur in specific types of cases. Does specialization also have the effect of increasing the judicialization of a constitutional court?

S. Cassese: In Italy, we have never had the same kind of specialization that one finds in some high courts. And I must tell you that I am strongly opposed to it. It is dangerous for a constitutional court to give, say, all tax cases all go to a specialist in tax law. The best way to make progress, in each area of the law, is to mix things up, to give criminal cases to a judge-rapporteur who is not an expert in criminal law, but perhaps administrative or commercial law. Otherwise, you risk having a one-judge constitutional court for specific types of disputes. With me on the Court was a close friend of mine-Franco Gallo [born 1937] — who was an expert tax lawyer. If all the complex cases had been given to him, nine years of tax jurisprudence would have been written by Gallo. Now one might say that, "since tax is a very technical area of law, such cases must go to Gallo." But we were strongly in favor of having Gallo report on family law cases, precisely because they would be very far away from tax or commercial law. The worst constitutional rulings on criminal law cases are most likely to be taken by specialists on criminal-not constitutional-law.

Question: Getting the law right, from the standpoint of specialists, may not be getting it right from the point of view of constitutional rights.

S. Cassese: Yes. Those who are specialist in criminal law need to learn that "right law," from the standpoint of constitutional rights, may be different from what is "correct" in criminal law, from the standpoint of the codes.

Question: The discussion of your idea of the Court, as a "public moralist," connects to a question that we also asked of Justices Barak and Grimm, concerning the situation in which judges find themselves when they confront hard cases involving rights. To what extent does rights adjudication comprise a species of applied moral reasoning?

S. Cassese: Adjudication and moral reasoning cannot be separated. As a judge, you have moral inclinations, but these must be considered alongside the constitutional law, rules of interpretation, and the commitments of your colleagues. From the dialogue among these three elements derives the decision.

The legal side becomes more visible in our rulings, while the moral aspects often remain unwritten. An example is the problem of same-sex marriage. Is a homosexual union a "family," and thus covered by the right to marry? The wise decision of the Court was that this is not a family, in the terms of Article 29 of the Italian Constitution on marriage, but a new type of "formazione sociale" under Article 2, that is, a social construct through which "new" rights can evolve. This understanding provides a legal basis for recognizing both the traditional Catholic idea of family, and the union. The judgment condemned-morally and legally-discrimination against homosexuals, while taking account of the "sacred nature" of the family according to Catholic doctrine. One cannot hope to solve such legal problems without addressing its moral dimension.

Question: You stress the fact that the constitutional court is not, formally, part of the judiciary, which was clearly emphasized by the founders of the new Italian constitution. The Constitutional Court occupies its own unique constitutional space, in classic separation of powers terms, neither "political" nor "judicial." Partly for that reason, you criticize the Court for defining itself too much 
in terms of a "judicial" organ. Is this due to the fact that there are career judges on the Court? Or is it due to a failure of imagination and will?

S. Cassese: In recruitment terms, the Italian Constitutional Court is partly an institutionalized representation of the three highest ordinary courts. We have three members of the Court of Cassation (the Supreme Court of civil and criminal law), one from the Council of State (the high administrative court), and one member of the Court of Accounts. These judges bring to the Constitutional Court their mentality, their culture. Our top clerks also come from the Court of Cassation or Council of State, who consider clerking in the Constitutional Court to be an honor, a promotion.

It is good to have career judges. But the three judges that are elected by the Court of Cassation have the same mind set. They bring with them a long career and experience. Typically, those who are elected have been - or are-presidents of a section of the Court of Cassation. It would be much better to appoint one more member of the Council of State, and only two from the Court of Cassation.

Question: Does adopting a "judicial” mindset also impact the Court's deliberations and the style of its rulings?

S. Cassese: Yes. In courts, you have to compare arguments, discuss alternative legal positions, consider different sides of the problem, and prepare to convince your colleagues, and to be convinced. These deliberations have clear implications for the members of a court, and the types of judgments they produce. This was new for me, as I had no experience as a practicing lawyer, in spite of my experience as a minister of government, adviser to prime ministers and to presidents, member of governmental advisory committees, and teacher at the specialized schools for the training of civil servant.

As for style, by the time I was on the Court there was a fixed style that everyone accepts and follows, which makes the technical part of the task relatively simple.

Question: Like the Italian Court, the French Constitutional Council also uses a terse, constrained style, in contrast to the German and Spanish courts, which have developed their own longer, more discursive, and argumentative styles. But the French Constitutional Council now regularly refers to internal conflict and alternative views, however briefly, if only to dismiss them. Its audience now knows when there were important splits within the Council. Should the Italian Court move in that direction?

S. Cassese: My idea was to have judgements which had less discussion of the arguments of the parties, but with more information on the different positions in the court. If we can't have full dissents, then we should develop dissenting opinions without names of the dissenters.

The Italian Constitutional Court has discussed introducing dissenting opinions on three occasions. The first time there was just one vote in favor, then two; when I was on the Court, we were four. In another twenty or thirty years, I predict that there will be dissenting opinions in Italy. During my term, I sought to introduce dissents; I also organized a regular seminar to discuss such a reform inside the Court, for judges, clerks, and senior staff. I proposed that we mention in our decisions - without naming the judges - the fact that alternative opinions had emerged in conference. We could then discuss the reasons-given for our differences. This would be a second-best solution-dissents without names. The proposal was not accepted. People still clung to the idea that the law is the law, and the law treats each legal question as having only one solution. God can speak only with one voice.

Question: A system without dissents typically generates less precise rulings, a cost of compromise. What about the informal "rules" within the Court? Is there was a norm to the effect that the justices should seek to reach as much consensus as possible during deliberations? That norm no longer exists in the United States Supreme Court, but Dieter Grimm tells us that it is very much alive on the German Court, along with dissenting opinions. 
S. Cassese: It is clear that the absence of dissents, either with or without names, makes decisions less clear. At the same time, there exists an unwritten rule: "Always try to achieve as large a majority as possible in support of any decision."

I was a rapporteur on one case which had to do with Berlusconi, ${ }^{5}$ and thus a highly political dispute. We had a long half-day discussion in which it became clear that my proposal had the majority of the court, but only a bare majority. Over lunch with a few colleagues, I found a way to expand the majority to two-thirds of the Court, which I then incorporated into my report. Larger majorities also make for stronger precedents.

If one wants to be a good constitutional judge, one must be an alliance builder. One cannot be passive. Good judges must proactively propose a solution; they must be reasonable and flexible; and they must be able to persuade and convince others that they can be persuaded in turn by the other side. In my nine years in the court, I recall at least ten important cases on which I changed my mind, based on debates in conference. I discovered that the other side was right, and that I was wrong. And that's the best part of being on a collegial court. Otherwise a court is divided, into parts red and blue, right and left, black and white.

Question: That is often the situation in the United States now. Decisions often reduce to a vote on competing ideological positions disguised as methodological disputes, with little or no in-person deliberations on contending views.

S. Cassese: In my opinion, this is a result of how American judges are recruited, given their appointment for life. These days, even Popes resign. But the problem is also the way in which the U.S. Supreme Court works. They meet; the Chief Justice collects opinions; then he appoints justice to draft a decision as representative of a potential majority. In the United States, one starts by trying to establish who is in the majority and who is in the minority. In Italy, it is the opposite: The building of the majority comes at the end. So much the better.

Question: The issue of dissenting opinions necessarily implicates the role of precedent.

S. Cassese: The Italian Constitutional Court always starts from the standpoint of its precedents, and I think this is true for well-established court. But what do we do with the bad precedents? The best solution is to overrule them. But the usual way is to marginalize bad decisions through interpretation, by distinguishing. This solution, too, leaves a problem-the old precedent remains. In the end, like all legal norms, precedents too must be interpreted, and interpretation is sometimes an exercise in pure manipulation.

\section{The Court and the Parliament}

Question: The development of new remedies for parliamentary violations of rights has transformed constitutional law. The Italian and German Constitutional Courts have been at the forefront of perfecting these remedies, whose purpose is to organize dialogues with parliament on the issue of how to "correct" statutory provisions in order to render them constitutional. These dialogic techniques also permit courts to escape the trap of seeing judicial review in rigid, binary terms - a statute is either constitutional or unconstitutional-while inviting the parliament to participate meaningfully in the process of correcting the statute. ${ }^{6}$

S. Cassese: In my opinion, the Italian constitutional court is the best court in the world at deploying these types of creative judgements, in effect, to manipulate the Government and Parliament to do what is right. Some observers see this as a weakness. One should decide the matter, yes or no, as if a judgment could have only one clear outcome. Of course, if the Parliament refuses to respect the deadline we have given for revising a statute, or ignores

\footnotetext{
${ }^{5}$ Silvio Berlusconi, Prime Minister of Italy in 1994-1995, 2001-2006, and 2008-2011.

${ }^{6}$ In the 1990s, these techniques diffused to systems as diverse as Canada, Colombia, and Taiwan. See AleC STONE SwEET \& Jud Mathews, Proportionality Balancing and Constitutional Governance: A Comparative and Global Approach ch. 5 (2019); Po Jen Yap, Constitutional Remedies in Asia (2020).
} 
the interpretive guidelines we have laid down, we will have to decide the case again, and to repeat ourselves more forcefully. In complex and politically controversial cases, it is much better to arrive at a solution through an iterated process: first the court reviews the statute; then the Parliament responds to the Court; and then the Court reviews the law again. This is how the Italian law on abortion and divorce were successfully revised, for example.

Question: Through structuring these "corrective revision" processes, ${ }^{7}$ the Court may wish to avoid giving the impression that it is, in fact, the supreme lawmaker, commanding Parliament. But dialogues do entail constraining Parliament, establishing a framework-boundaries-in which Parliament may choose.

S. Cassese: Can I tell you a secret? Those who think that judges should not make the law, should not be on a constitutional court. They should stay at home where it's safe. As a judge, one must be ready to take responsibility for one's decision. This is true for every judge, but it is harder for constitutional judges to hide the fact that when they decide, they also make law.

Question: When they adjudicate parliamentary legislation, they make law - simultaneouslyon two levels: The constitutional and the statutory.

S. Cassese: Adjudicating legislation means interpreting a constitutional provision and, at the same time, evaluating an act of Parliament. If the latter conflicts with the constitutional interpretation, then the Court declare it to be unconstitutional. Most of the work of a constitutional court can be modeled as such a dual procedure.

Question: Examples of positive cases of dialogue include those in which the Court suspends the effects of a ruling on unconstitutionality to give Parliament an opportunity to correct the impugned legislation. But one also finds negative cases, in which Parliament proves incapable of reaching compromises on very sensitive issues, for example, assisted suicide and biological testing.

S. Cassese: To make such dialogue work, one needs underlying political pressure. Otherwise, Parliament might simply freeze up and remain frozen. Our job is to help Parliament see how it can move forward, and why it is in Parliament's own interest to do so. The Court needs the support provided by those who are affected by our rulings, the media, and so on. It's a political process.

Question: Around the world, these types of constitutional dialogues between judges and parliaments are now heavily structured by the proportionality test. As Aharon Barak and others have emphasized, the most effective constitutional judges in the world uses proportionality analysis to delineate a "zone of proportionality" within which the parliament can legitimately legislate. How important has the proportionality framework been in Italy? How do you see its development in Italy, given that a more inchoate standard-reasonableness-has deeper roots in Italian public law, and remains a point of reference even on the Constitutional Court? This would seem to be a further effect of hyper-judicialization: the failure on the part of the Court to replace the old reasonableness tests with the proportionality test, a more formalized reasonableness test, if you will.

S. Cassese: The Italian Constitutional Court has for long time derived the principle of reasonableness from the equality clause of article 3 paragraph 1 of the Constitution. Subsequently, it has also invoked the proportionality principle, as a general principle of constitutional law on its own. But it has never developed the proportionality principle, by establishing different tests. By avoiding formalization, it has gained more flexibility in its reasoning.

\section{The Italian Court and Inter-Judicial Relations}

Question: In legal systems in which a constitutional court co-exists with a supreme court, or multiple supreme courts, jurisdictional conflicts erupt regularly. In Italy, this conflict was partly managed through the development of the doctrine of the "living law," a kind of mutual recognitionnegotiated by the Constitutional Court and the Court of Cassation, also called Supreme Court—of

${ }^{7}$ Alec Stone Sweet, Governing With Judges: Constitutional Politics in Western Europe ch. 3 (2000). 
shared interpretive authority. Each high court knows that it needs the support of the other to be effective. During your tenure on the Court, how did you perceive the rivalry between the Supreme Court and your Court?

S. Cassese: When I arrived on the Court, the major problems between Cassazione and the Constitutional Court had largely been resolved. Generally, I would not say that we experienced important conflicts with the ordinary courts. We spent much more time and energy working to establish good relations with the two European courts, and with foreign constitutional courts, the French and the German, for example.

After all, three judges elected by the Court of Cassation sit on the Constitutional Court, and many of these had spent years serving as clerks at the Constitutional Court. In 2020, all three judges had spent from ten to twenty years as clerks at the Constitutional Court. It is also true that ordinary judges, and among them members of Cassation, regularly bypass the Constitutional Court when they can send a preliminary question to the European Court of Justice.

The Court is careful to be diplomatic in our relations with Court of Cassation and Council of State. We need the support of both, because the only way an individual can get to the Constitutional Court is through a referral from them. If the judiciary refuses to refer cases, we would have little or no work to do. Diplomacy and dialogue is built into this institutional fact. It is also important that the Court now encourages every ordinary judge to interpret and apply laws in conformity with the Constitution. This leaves room for a judge of an ordinary court to play the role of a constitutional judge. This is good diplomacy, but it is also quite dangerous.

Question: Dangerous, one presumes, because the ordinary courts could then seek to control outcomes, attempting to have the "final word," while marginalizing the Constitutional Court?

S. Cassese: Yes. Moreover, they can bypass the Constitutional Court by referring cases to one of the European Courts.

Question: The absence of a German-style constitutional complaint procedure weakens the Court's capacity to monitor the compliance of the ordinary courts with the Constitutional Court's jurisprudence. Would you be in favor of introducing a procedure to give individuals access to the Court?

S. Cassese: No. The Italian Court already has too many cases.

Question: A related issue concerns the relationship between the Italian Court and the European courts. During your time on the Court, two major events took place. The first featured the "twin judgments" of 2007, ${ }^{8}$ which recognized the direct applicability of the European Convention of Human Rights (ECHR) within the Italian legal order, albeit with an important caveat. An ordinary court, the Court held, could not disapply an Italian statute considered to be a violation of the Convention on its own, that is, without first asking the Constitutional Court for permission to do so. Second, in 2008, the Constitutional Court, for the first time, sent a preliminary reference to the Court of Justice of the European Union (CJEU), ${ }^{9}$ which confirmed the latter's interpretive authority.

S. Cassese: Important steps, but they came too late, if you take into account that the EU and the ECHR had already been in place for a half century. Why so late? Because, national legal orders are generally not inclined to openness vis-à-vis other legal orders, and Italy is no different. But also for other reasons, like prestige or power-the desire to be the ultimate legal authority.

Question: Most of the major constitutional issues involving EU law were resolved before you joined the Court, through the Granital judgment [1984]. One effect of Granital ${ }^{10}$ was to undermine dualist orthodoxies, such as the doctrine of lex posteriori derogat (legi) priori, at least with

\footnotetext{
${ }^{8}$ Corte Cost. (Constitutional Court) 22 October 2007, n. 348, 349 (It.).

${ }^{9}$ Giorgio Repetto, Pouring New Wine into New Bottles? The Preliminary Reference to the CJEU by the Italian Constitutional Court, 16 German L.J. 1449 (2015).

${ }^{10}$ Marta Cartabia, The Italian Constitutional Court and the Relationship Between the Italian Legal System and the European Union, in The European Court and the National Courts: Legal Change in its Social, Political, and Economic Context 133-46 (A-M. Slaughter, A. Stone Sweet, and J. Weiler eds., 1998); Giacinto della Cananea, The Italian Constitutional Court and the European Court of Justice: from separation to interaction, 14 EUROPEAN PUBL. L. 523 (2008).
} 
respect to the application of EU law. The 2007 rulings were moves in the same direction with respect to the direct effect of the ECHR. Since European rights now cover virtually every aspect of Italian law, in one way or another, why do so many Italian professors still insist that Italy remains a dualist legal order when it comes to European law?

S. Cassese: A large part of Italian scholarship is very parochial. There is no hope for them. Things must change, but it is almost impossible to do. Too many Italian professors are not scholars at all, but modest practicing lawyers who from time to time teach and write.

Question: In 2012, Stone Sweet presented a paper at the New York University Law School on the impact of the incorporation of the ECHR into domestic legal orders. ${ }^{11}$ There were many constitutional judges in the room, having just come from the annual Yale conference of constitutional judges. One of the arguments presented was that, from the point of view of rights protection, France now had three de facto constitutional courts: the Conseil constitutionnel, the Cour de cassation, and the Conseil d'État, as did Italy. This claim was immediately contested by the French and Italians in the audience. But then a member of the French Constitutional Council, followed by Sabino Cassese, intervened in order to support the view, respectively, that France and Italy now possessed three constitutional courts. Why were you, as a member of a constitutional court, comfortable with this view, rather than jealous of your Court's authority?

S. Cassese: Let's start with a practical problem. When I became a judge, the Court produced approximately 500 judgments per year; when I left we were at 300, and now there are about 250 . But twenty years before, the court produced more than 1000 decisions every year! So, it's not just a question of whether one is jealous of one's power as a judge.

Question: Judgments nn. 348 and 349/2007 (concerning the status of the ECHR in the Italian legal order) should be understood as a response to docket overload?

S. Cassese: Yes. The workload was so enormous that we had to take this type of decision, given the importance of rights protection to the system as a whole. We changed the law, insisting that every ordinary judge respect both the Convention and Italian constitutional rights, simultaneously as it were, leaving intact our monopoly over the authority to invalidate parliamentary statutes. In my opinion, we still have a supreme constitutional court, but the rulings are a turning point. We introduced decentralized constitutional review in 2007. A centralized body must sometimes be wise enough to decentralize. We decided to share our power with other judges.

Question: Most students in Italy are taught differently: There can be only one constitutional judge, one final word on conflicts of norms and jurisdictions.

S. Cassese: Only the Constitutional Court can declare a statute unconstitutional. But we have held, in effect, that ordinary judges must interpret any law under review in a manner that is consistent with the Constitution, and the EU Charter and Convention, whenever possible.

Today, Italian constitutional review is divided into two parts-weak and strong. Ordinary judges exercise weak constitutional review, not because they cannot act as constitutional judges, but because they are not allowed to annul the impugned law without our permission. Otherwise, they do what a constitutional court does. When it comes to the substantive content of the review process, it is more or less the same. I agree that Italy has many constitutional courts, de facto. But only the Constitutional Court has a pair of scissors; it uses them to cut out unconstitutional law, while the other courts neither have the means nor the authority to do so.

Question: It is by now well-known that ordinary judges in Italy will, at times, for their own reasons, refuse to apply statutes in force on the grounds that they violate the ECHR, but without first asking the Constitutional Court for permission. This practice is forbidden under the 2007 rulings. How tolerant of this situation-one of pluralism rather than hierarchy- do you think the Court ought to be?

\footnotetext{
${ }^{11}$ Alec Stone Sweet, A Cosmopolitan Legal Order: Constitutional Pluralism and Rights Adjudication in Europe, 1 GLOB. Cosmopolitanism 53 (2012).
} 
S. Cassese: First of all, if one is a constitutional judge, the most important goal is to protect rights. One should not worry about who is protecting the rights. We have to accept the idea that there are rights in our three constitutions - of Italy, the EU, and the Council of Europe. All three of these charters are constitutional in nature, and all three courts-the Italian Court, the CJEU, and the Strasbourg Court-are bona fide constitutional courts. Our main task is to protect rights. We have to be open to dialogue, mutual respect, and to adjusting to one another. It is better to have multiple judges protecting rights, compared to a situation with only one judge. And we are better off enlisting ordinary judges to help us.

Question: One common, more literal, reading is that Rulings 348 and 349/2007 are a defensive reaction on the part of the Constitutional Court to ensure its centrality with respect to constitutional judicial review, given the growing importance of the Convention. ${ }^{12}$ Were some of your colleagues on the Court more anxious than you to confirm that the Court alone has the power to disapply statutes when in conflict with the ECHR?

S. Cassese: My interpretation at the time was that we had to open the Italian legal order to the ECHR, and that the best way was to accept judicial pluralism. At the same time, we accepted the principle that parliamentary legislation must respect Italy's international obligations. Stating clearly that Italian law must comply with the ECHR or itself be unconstitutional was the best way to do so, while also preparing the way for a continuous conversation with the Strasbourg Court.

The 2007 decisions were taken only after a great many internal deliberations, but also many informal consultations. All of the members of the court knew that these rulings would be of great importance, that we were at a turning point. In my nine years on the Court, I took extensive notes only for some eight or nine other decisions, perhaps even less. We knew that we were going to take one of the most important decisions in the history of the court. Again, in my view its main purpose was not defensive, but rather to bring the ECHR, as a legal system into a closer conversation with the Italian order.

Question: Dialogue between courts also brings competition between courts, and sometimes open conflict.

S. Cassese: When it comes to rights protection, we should reject the view that law and courts must be part of some kind of pyramid-like structure. We should assume that they are different sources of rights, different courts, different types of litigants, different systems, and these can and must interact with one another. At the same time, we have common European constitutional traditions, which means accepting both the principle of margin of appreciation and the supervisory authority of the Strasbourg Court. We should welcome more competition, more courts, more points of view. There is a price to pay. More competition between courts may mean the propagation of different interpretations of the legal norms. But the costs are worth benefits. ${ }^{13}$

Of course, these costs are mitigated somewhat by doctrines of counter limits, that the rulings of supranational courts may not threaten the core constitutional values of the member states, for example. I support such counter-limits.

Question: As you have stressed, the 2007 rulings express an openness to the ECHR, recognizing its direct effect in the Italian order. For its part, the CJEU developed its competence in the domain of rights with reference to common constitutional traditions, and to the ECHR, which it recognizes as a source of general principles of EU law. Further, Article 6(3) of what is now the TEUand on which you are now writing-echoes the point. Nonetheless, the 2007 rulings of the Italian Court confer on the ECHR an inferior status, compared to EU law. Simply put, the ordinary courts may, on their own, refuse to apply statutes found to conflict with EU law; but they must ask the Constitutional Court's permission to do the same with respect to statutes found to be in conflict

\footnotetext{
${ }^{12}$ Including Oreste Pollicino, The European Court of Human Rights and the Italian Constitutional Court: No 'Groovy Kind of Love', in The UK and the European Court of Human Rights: A Strained Relationship ch. 18 (K. Siegler ed., 2015); Francesca Biondi Dal Monte \& Filippo Fontanelli, The Decisions No. 348 and 349/2007 of the Italian Constitutional Court: The Efficacy of the European Convention in the Italian Legal System, 9 GERMAN L.J. 889 (2008).

${ }^{13}$ See Sabino Cassese, When Legal Orders Collide: The Role of Courts (2010).
} 
with the Convention. The rulings subject the ECHR to what is, in effect, the regime that governed the status of EU law, pre-Granital. ${ }^{14}$ How do you think that this difference in treatment can be justified?

S. Cassese: One has to recognize that there are different degrees of supranationality, and these differences have consequences. The EU and the ECHR generate different types of law. The EU treaties comprise a "constitutional" treaty, which is not a contradiction in terms. This constitution governs an entire political system: a parliament, an executive Commission, and an intergovernmental Council. There is an entire machinery for making and implementing law and for monitoring compliance. There is a currency and bonds denominated in that currency, and a Central Bank that manages an enormous economy. So, behind the EU, there is a structure, an entire political system. What is behind the ECHR? Nothing much but a court.

Question: Is this a good reason for the Court not to harmonize its jurisprudence, by putting the ECHR on equal footing with EU law, or simply a step in a larger process? It would seem that the Court will have no choice but to adopt a common position at some point.

S. Cassese: I share your view, but you must also consider that the two Court have different powers, and therefore a different impact on the national legal orders.

Question: Today, inter-judicial dialogue rests on an identifiable set of norms and practices that continuously evolves.

S. Cassese: Dialogue is an ongoing procedure. As you mentioned, I am now working on the problem of common European constitutional traditions (Article 6 [3] of the Treaty of the European Union). How does one establish if there is a national tradition, and whether that tradition is common? The only way is through inter-judicial dialogue. There is simply no other way to address this question. We must accept that each European state possesses a national constitution, and that many also have two European constitutions: The EU Charter of Rights and the ECHR. Behind these three constitutions are domestic judges who must respect all of these constitutional provisions in their rulings.

This implies that each national jurisdiction, mainly the apex courts, must assess national traditions comparatively in order to establish features in common to be taken into consideration. If they do, supranational courts would be able to derive a common set of supranational principles of European law, which in turn would bind the national courts.

It is also important for judges on the national constitutional courts to know and understand one another better. We have similar responsibilities and similar problems, including how to implement consistent interpretations of European law. Today, there is, and must be, a horizontal intermingling of courts. The idea of "common constitutional traditions" implies a horizontal procedure, by which one analyzes A, B, C, D, and how each has evolved in, say, the twenty-seven countries of the European Union. Dialogue among courts provides the foundation of building a European law, and always has. It is an exercise in comparative law with real-world consequences.

Question: The EU, through its court, has made a sovereignty claim, one that is not actually accepted by most constitutional courts in the member states. The Strasbourg Court has not made the same supremacy claim, although at times it implies its own primacy in interpreting rights. Does that matter?

S. Cassese: From a doctrinal point of view, yes. But in practice, we treated the European courts in the same way, with the same respect, deference, and willingness to cooperate. Today, the Court

\footnotetext{
${ }^{14}$ For present purposes, the Granital ruling is significant in that the Italian Constitutional Court authorized the Italian ordinary courts to disapply statutes found to be in conflict with EU law, without prior permission to do so. Corte Cost. (Constitutional Court), 8 June 2008, n. 170, Giur. it. 2008 (It.). In contrast, the twin judgments of 2007. N. 348 and 349 , supra note 8 . While recognizing the applicability of the ECHR within the domestic legal system, prohibited the ordinary courts from setting aside statutes considered to be incompatible with Convention rights, unless authorized to do so by the Constitutional Court.
} 
is even willing to send the CJEU a preliminary reference, and it will support the consultative procedure enshrined in Protocol no. 16 of the ECHR. ${ }^{15}$

Question: In 2009, you published a prescient book with a wonderful title: I Tribunali di Babele [The Courts of Babel: Judges in Search of a New Global Order], which argues that courts are rapidly developing creative ways of engaging with one another across jurisdictional boundaries, and indeed, they must do so to be effective in a globalized world.

S. Cassese: Conflicts between states can be solved by wars, negotiation or third party dispute settlements. Judges are rapidly replacing the first two types of dispute settlements at least in matters of "low politics". Moreover, courts may establish rapidly networks at a supranational level. This is the reason why the development of supranational courts, there are approximately 120 , is very important.

Question: The discussion raises a sensitive question: your opposition to the Italian Court's 2014 decision on the liability of Germany for crimes committed during the Second World War. That ruling comforted positions taken by the Italian civil courts, in the context of a series of suits against Germany that the civil courts had found to be justiciable. Yet it also put the Italian Court in conflict with the International Court of Justice, which in 2012 had declared that such suits were blocked by principles of sovereign immunity. ${ }^{16}$

S. Cassese: I was nearing the end of my term on the Constitutional Court when it took that terrible decision on German liability. I spoke strongly against the decision, so much so, that I was ready to resign rather than to be associated with it. In the end, I did not participate in the meeting in which the decision was approved. I did publish a kind of dissenting opinion, after I left, in a memoire about my time on the Court.

Question: We are interested in your views on this situation because it placed two values - both close to your heart-in evident conflict. On the one hand, you have been an outspoken advocate of dialogue and mutual recognition between courts, in particular, between domestic constitutional courts and international courts. On the other hand, you are something of an absolutist with respect to access to justice and the right to an effective judicial remedy when violations of fundamental rights are involved. In this case, the Italian Court based its decision on Article 24 of the Italian Constitution- "All are entitled to institute legal proceedings for the protection of their own rights and legitimate interests" - which is, of course, backed up by Article 13 of the ECHR (the right to an "effective remedy"). You thought the constitutional court should have sided with the International Court of Justice [ICJ].

S. Cassese: I did, because I saw the decision as a blow against international law, and against those provisions of the Constitution that open the door to international law which allow us to incorporate it into the Italian legal order. I saw the ruling as a form of "legal protectionism." The Italian petitioners had already enjoyed access to German courts and, indirectly, to the ICJ. If one accepts that one is not living alone on the Earth, then one must also acknowledge that trustworthy judges can be found everywhere. Access to justice under Article 24 means access to justice, but not only to Italian justice.

Moreover, Germany had already paid significant reparations, funds that Italy had used to rebuild housing and infrastructure destroyed in the war. Italy chose not to provide compensation to individual victims. I thought that, under such circumstances, it is for Italy to settle with the victims. Or Germany and Italy could have entered into negotiations to find a settlement. Either path might have permitted the Court to avoid a confrontation with the ICJ.

Question: How would you respond to those who see the Italian Court's ruling not as a parochial "protectionism," but as cosmopolitan? The idea here, shared by many, is that the ICJ's judgment is deeply flawed from the point of view of international law. The ruling fails to respect the right to a

\footnotetext{
${ }^{15}$ Establishing the competence of the Strasbourg Court to render advisory opinions, upon request from domestic high courts.

${ }^{16}$ Jurisdictional Immunities of the State (Germany v. Italy), Judgment, 2012 I.C.J. 143 (Feb. 3, 2012).
} 
judicial remedy - which is, arguably, jus cogens - on the basis of an old-fashioned view of customary international law that had evolved prior to the modern era of human rights. Indeed, Justice Cançado Trindade of the ICJ, and formerly president of the Inter-American Court, wrote a powerful dissent in such terms, declaring that domestic judges should refuse to comply with it. ${ }^{17}$ From this point of view, the Italian Constitutional Court's [ICCs] ruling could be seen as dialogic, challenging the ICJ to reconsider how it interprets sovereign immunities, updating the latter in light of the modern priority we give to rights protection. ${ }^{18}$

Imagine for a moment that the Italian Court had rejected the reference, in effect, adopting the position of the ICJ on German immunity in domestic courts. The plaintiffs then petition the Strasbourg Court? Do you have any thoughts on how the European Court might or should react?

S. Cassese: No, but I think that a supranational court would have considered that the right to a judge and an effective remedy had properly been recognized.

\section{E. Challenges, Past and Future}

Question: Looking back on your career from the standpoint of a former constitutional judge, how would you assess public law teaching and scholarship in Italy today? What advice would you give to younger law professors?

S. Cassese: Here are some suggestions. First, be comparative; do not only study national law. Second, cross disciplinary borders, as scholarship progresses on the borders. Third, decisions taken by the executive are as important as judicial and legislative decisions; do not forget that executives too make the law through interpreting it.

As you know, I have always taught from cases, not treatises, and urged students to take into account what is behind the written law. And I would suggest to younger colleagues not to think that the law is only what is written in the Gazzetta Ufficiale (i.e. the official journal). Law is a product of complex social forces, and is itself a social process, full of conflicting interpretations. Judge-made law is never permanent law, but always provisional. As a judge, one may want to give the impression that the constitutional court has the "final word" but, in reality, a "final" word does not exist. Important rulings are just one part of a continuing process.

Question: One orthodox response: “All that's well and good, but what you say does not actually concern 'the law,' but 'sociology."'

S. Cassese: The Germans have this positivistic disposition. On one side are the dogmatics; on the other side is the written law. Then the two are combined, which allows one to build this impressive intellectual architecture. But this is a very simplistic way of looking at law. It is also strange because another, perhaps truer, German tradition-is that of Savigny [Friedrich Carl von, 1779-1861], who rejected these views. Germans often say that Savigny is the great father of German law, but they rarely follow him.

Question: Looking back from the perspective of your experiences on the constitutional court, what changes would you want to make to the Italian constitution or to the Constitutional Court and its operations?

S. Cassese: To the Constitutional Court, I would suggest the introduction of dissenting opinion and a more diverse membership. One Court of Cassation judge is enough; instead, there should be two judges drawn from the lower courts.

As already discussed, the Italian political system would benefit from having the President of the Court assume the role of a public moralist in the name of the Constitution. If so, the President of

\footnotetext{
${ }^{17}$ Dissent of Judge Cançado Trindade, Jurisdictional Immunities of the State (Germany v. Italy), 2012 I.C.J. 143 (Feb. 3 , 2012).

${ }^{18}$ See Chantal Meloni, Jurisdictional Immunity of States: The Italian Constitutional Court v. the International Court of Justice?," ZEITSCHRIFT FÜR INTERNATIONALE STRAFRECHTSDOMATIK, 6, 7 (2015), http://www.zis-online.com/dat/artikel/ 2015_6_931.pdf.
} 
the Court should be appointed by the Italian President. Currently, the lack of continuity at the head of the Court makes it very weak in its relations with the other governing institutions. In the past, some Presidents only served for a few months. Having a more stable and respected presidency would also make the staff more effective.

Question: And the Constitution itself? Are there are provisions you would change given that we are not living in the world of the 1950s?

S. Cassese: The Constitution is already flexible enough, and one of the Court's major tasks is to update it through interpretation.

Question: At present, in Europe and beyond, systems of constitutional justice-in which rights are robustly protected by powerful constitutional courts - appear to be in trouble. How do you see the state of the Italian Court with regards to its political legitimacy in near future? And what kind of advice would you give constitutional judges who face situations like those in Hungary, Brazil, or Poland, where judicial review is under attack by political elites?

S. Cassese: For the Italian Constitutional Court one may employ the metaphor coined by Johann Wolfgang Goethe [1749-1832] for Roman law: "It's like a duck that disappears under the water which, from time to time, reappears." Sometimes, the Court acts on the progressive side, sometimes it appears to be conservative. This feature of the Italian Court has advantages, insofar as it is hard to say if it is on the "right" or the "left" politically.

What can you do with hostile leaders of political parties that win legislative majorities? Help must come from the outside in conjunction with domestic groups who support rights and judicial review. I've been talking to people, members of courts, professors in both countries, and they are begging for global support. One must also try to build global public opinion. The EU has shown itself to be too weak, with Hungary and Poland, but also with Turkey. So, I think the only possibility is building a virtuous circle that links pro-democracy governments, international organizations, NGOs, and civil society, in common efforts to support fundamental rights and independent courts and to put pressure on those who are seeking to destroy them.

I share the view that we had an important period in which great progress was made, and now we are experiencing a certain regression. On the other side, one sees the development of a global public sphere, of the kind that Habermas theorized. If an African-American is killed by policemen in an American city, people see it on TV all over the world and the reaction is global. There now exists an ongoing process of "education," so to speak, in favor of human rights. People are also much more mobile. The world now has more than seven and a half billion people, and they travel, live, and work abroad, migrate. The politics of rights protection can't be kept strictly national and it never truly was.

Cite this article: Stone Sweet A, della Cananea G (2021). A Conversation with Sabino Cassese. German Law Journal 22, 1526-1540. https://doi.org/10.1017/glj.2021.90 